\title{
"Entrepreneurship education and its impact on the entrepreneurship career intentions of vocational education students"
}

\begin{tabular}{ll} 
AUTHORS & $\begin{array}{l}\text { Takawira Munyaradzi Ndofirepi } \\
\text { Patient Rambe }\end{array}$ \\
& $\begin{array}{l}\text { Takawira Munyaradzi Ndofirepi and Patient Rambe (2017). Entrepreneurship } \\
\text { education and its impact on the entrepreneurship career intentions of vocational } \\
\text { education students. Problems and Perspectives in Management, 15(1-1), 191- } \\
\text { 199. doi:10.21511/ppm.15(1-1).2017.06 }\end{array}$ \\
\hline ARTICLE INFO & http://dx.doi.org/10.21511/ppm.15(1-1).2017.06 \\
\hline DOI & Wednesday, 10 May 2017 \\
\hline RELEASED ON & Thursday, 08 December 2016 \\
\hline RECEIVED ON & Monday, 06 February 2017 \\
\hline ACCEPTED ON & \begin{tabular}{l}
$(c)$ EY-No \\
\hline LICENSE
\end{tabular} \\
\hline Ihis work is licensed under a Creative Commons Attribution-NonCommercial 4.0 \\
\hline JOURNAL & "Problems and Perspectives in Management" \\
\hline ISSN PRINT & $1727-7051$ \\
\hline ISSN ONLINE & $1810-5467$ \\
\hline PUBLISHER & LLC “Consulting Publishing Company “Business Perspectives" \\
\hline FOUNDER & LLC “Consulting Publishing Company “Business Perspectives"
\end{tabular}

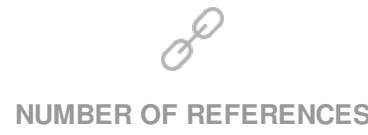

47
NUMBER OF FIGURES

0
NUMBER OF TABLES

5

(C) The author(s) 2023. This publication is an open access article. 
Takawira Munyaradzi Ndofirepi (Zimbabwe), Patient Rambe (South Africa)

\title{
Entrepreneurship education and its impact on the entrepreneurship career intentions of vocational education students
}

\begin{abstract}
The rich body of literature examining the entrepreneurship education-entrepreneurship intention relations tends to neglect the influence of contingent and other mediating factors on the relationship. This elusion creates an erroneous assumption that entrepreneurship intentions are insulated from external influences and the entrepreneurship educationintentions relationship is an automatic, directly linear interaction. Contesting this premise, this research explores the influence of exposure to entrepreneurship education (EE), mediated by precursors (such as attitude, subjective norms and perceived behavioral control) to entrepreneurial intentions on the actual entrepreneurship intentions (EI) of vocational education students at a particular institution in Zimbabwe. Drawing on a cross-sectional research design and 154 randomly selected students, the study examines the extent to which they intended to engage in entrepreneurship careers in the near future. A non-parametric technique, the Spearman correlation test, and regression analysis were employed to test the relationships between EE on the direct determinants of EI, between the immediate determinants of EI and actual EI and to test a number of predictive effects. The results demonstrate that EE had a positive correlation with the direct determinants of EI. In addition, EE predicted all the immediate determinants of EI, except for subjective norms. Lastly, there was no evidence to support a direct predictive effect of EE on EI, controlling for other psychological factors. To a large extent, the results validated the Theory of Planned Behavior as a guiding tool for estimating any premeditated entrepreneurial behavior. Thus, the Theory remains an invaluable theoretical lens for academics, educators and policymakers' evaluation of effective ways of enhancing the grooming of potential entrepreneurs.
\end{abstract}

Keywords: entrepreneurship education, entrepreneurship intention, theory of planned behavior, vocational education.

JEL Classification: M10.

Received on: $8^{\text {th }}$ of December, 2016.

Accepted on: $6^{\text {th }}$ of February, 2017.

\section{Introduction}

Concerns about the scourges of unemployment and poverty amongst the youth, particularly schoolleavers and college graduates, have become central issues in the economic policy discourse in numerous developing countries such as South Africa and Zimbabwe (Kew, Namatovu, Aderinto, \& Chigunta, 2015; Masinire, 2015). For instance, Zimbabwean high schools and tertiary education institutions perennially churn out thousands of school-leavers and graduates who face serious challenges in securing decent formal employment opportunities (Masinire, 2015). While the dysfunctional and badly managed economy is often conceived as a source of such economic malaise (see Bhebhe \& Mahapa, 2014; Rusvingo, 2015), entrepreneurial critics question this anomaly arguing that it is normally in such deeply fragmented, disorganized economic scenarios that entrepreneurs employ their tolerance for ambiguity and complex uncertainty to generate economic opportunities (Kirzner, 1999).

Projecting this view, entrepreneurship commentators present a different set of questions bordering (1) on the efficacy of entrepreneurial programs and by

(C)Takawira Munyaradzi Ndofirepi, Patient Rambe, 2017.

Takawira Munyaradzi Ndofirepi, Kwekwe Polytechnic, Zimbabwe. Patient Rambe, Dr., Department of Business Support Studies, Faculty of Management Sciences, Central University of Technology, South Africa.

This is an Open Access article, distributed under the terms of the Creative Commons Attribution-NonCommercial 4.0 International license, which permits re-use, distribution, and reproduction, provided the materials aren't used for commercial purposes and the original work is properly cited. extension, (2) their capacity to predict entrepreneurial intentions. Such perplexing questions shift the discourse from the teleological functions of the economy towards the consequential premise of entrepreneurial educational outcomes.

The efficacy of entrepreneurial education (EE) and its capacity to predict educational outcomes such as entrepreneurial behavior has been a staple discourse over the last decade (Bae, Miao, Qian \& Fiet, 2014). One of the most interesting dimensions of the EE debate is the perceived capacity of EE to predict entrepreneurial intentions (Weber, 2012; Linan \& Chen, 2009). Despite researchers' intriguing interest in exploring the entrepreneurial education-entrepreneurial intention relations, one of the discomforting features of such research is a tendency to downplay the effect of contingent factors (e.g., gender and age) on the relationship. We, therefore, argue that this (deliberate or unintended) elusion creates an erroneous assumption that entrepreneurial intentions are insulated from external influences and the entrepreneurial educationintentions relationship is an automatic, directly linear interaction. Contesting this position, the current study draws on the Theory of Planned Behavior to demonstrate mediated nature of EE-EI relationship by the incorporating intervening variables such as subjective norms, perceived behavioral control and attitudes into this relationship, as well as demographic and other psychological factors. In view of the foregoing discussion, the current study investigates the following research questions: 
- Is there a statistically significant relationship between EE and attitude towards entrepreneurship?

- Is there a statistically significant relationship between EE and subjective norms?

- Is there a statistically significant relationship between EE and perceived behavioral control?

- Do attitudes towards entrepreneurship, subjective norms and perceived behavioral control of respondents predict their EI?

- Is there a statistically significant direct relationship between EE and EI?

The rest of the paper is structured as follows: first, the research background is provided. This is followed by the literature review and theoretical framework. Then, the research methodology is presented. Next, the findings are presented and discussed. The paper concludes with recommendations, implications for future research and concluding remarks.

\section{Research background}

1.1. High unemployment and "vendor graduates". The Zimbabwean economic landscape is awash with discomforting news of graduate unemployment. Bhebhe \& Mahapa (2014) and Rusvingo (2015) estimate the formal unemployment rate at above $80 \%$. While Zimbabwean universities were reported to churn tens of thousands graduates annually, this luminary picture is overshadowed by "vendor graduates", which have just become a perennial feature of the economic meltdown (Rambe, Ndofirepi, \& Dzansi, 2015). Many graduates find themselves engaging in unsophisticated menial jobs predominantly located in the informal sector of the economy such asvending, car washing, car watching, making and selling simple crafts, gold panning, selling second-hand clothing and cross border trading (Murinda, 2014). These vendor graduates are just disguised underemployed or unemployed persons in the country. In view of this unfortunate scenario, entrepreneurship studies have explored measures to mitigate the souring youth unemployment scourge in Zimbabwe and neighboring countries such as South Africa (Mushipe, 2013; Shambare, 2013; Fatoki, 2014).

1.2. Zimbabwean entrepreneurial program: an overview. Entrepreneurship, which is strongly conceived to create employment, stimulate economic growth and leverage social well-being, is often applauded as a fundamental solution to the quadruple challenges of high youth unemployment, poverty, inequality and social deprivation (Pruett, 2012; Maritz \& Brown, 2013; Pouratashi, 2014; Roxas, 2014; Brixiova, Ncube,

\& Bicaba, 2015). This partially explains the proliferation of EE programs and courses at various levels of the education spectrum in both the developed and developing countries such as Zimbabwe. EE is gen- erally intended to facilitate the transfer of knowledge, skills and attitudes associated with new venture creation and management (Liñán, RodríguezCohard, \& Rueda-Cantuche, 2011). It can be contended, therefore, that national governments hail entrepreneurship development programs as alternatives to seeking employment and as integral to employment creation, income generation, advancing social development and promoting social cohesion.

In Zimbabwe, all technical and vocational education and training (TVET) institutions, which offer the Higher Examination Council (HEXCO) qualifications offer a compulsory EE program in order to widen students' career options after graduation. At the same time, universities in the country are increasingly offering various EE programs ranging from certificates to degrees (Ndofirepi, 2016). Despite the enthusiasm for $\mathrm{EE}$, the aforementioned high graduate unemployment and underemployment points to the incalculable rift between entrepreneurial education programs and entrepreneurship outcomes (e.g., venture creation, job creation, income generation, social empowerment, etc). The preceding observation cements Mwasalwiba's (2012) assertion that lack of coherent proof of the impact of EE always triggers serious doubts about its efficacy. By extension this raises perturbing questions not only about the EE-entrepreneurial intentions relationship, but also the capacity of EE to foster appropriate psychological dispositions (i.e. attitudes, subjective norms and perceived behavioral control) that give effect to entrepreneurial behavior.

Studies have examined the impact of EE on entrepreneurship outcomes such as the creation of new ventures, new jobs, skills, attitude and other psychological mind-sets acquired from such programs (Fayolle \& Gailly, 2008; Hattab, 2014; Liñán et al., 2011; Weber, Graevenitz, \& Harhoff, 2009). Due to the varying contexts in which these studies were conducted including the methodological caveats often given, some studies have yielded inconsistent results (Fayolle, Gailly, \& Lassas-Clerc, 2006; Souitaris, Zerbinati, \& Al-Laham, 2007; Oosterbeek, Van Praag, \& Ijsselstein, 2010), while the extent of generalization of these studies has been severely constrained. One of the peculiarities of such studies is that neither have they foregrounded technical and vocational education contexts nor dealt with the impact of EE in struggling developing economies. To close this research gap, therefore, the current study pays special attention to the influence of entrepreneurial education rendered in Zimbabwean vocational education institutions on the antecedents of EI (e.g., psychological dispositions such as attitudes, subjective norms, and perceived behavioral control) and EI. 


\section{Theoretical framework}

Consistent with the postulation that the EE-EI relationship is neither direct nor operates in a vacuum, but is rather mediated by psychological functions such as attitudes, subjective norms and perceived behavioral controls, the widely employed Ajzen's Theory of Planned Behavior informs this study. The underlying assumption of the Theory is that human behavior is largely preconceived and deliberate. Thus, entrepreneurship, like most forms of human behavior, is assumed to be intentional (Ajzen, 1991, 2015). It can be inferred from this premise that entrepreneurship cannot be conceived as a coincidental, serendipitous occurrence of an unconscious individual, but rather a deliberately orchestrated human endeavor.

According to Ajzen (1991), human intentions are subject to diverse endogenous and exogenous factors. This theorization raises critical questions on whether such internal and external effects are instigated directly or indirectly through other factors. The theory underscores that only attitude, subjective norms and perceived behavioral controls have a direct effect on intention. This postulation's implication is that only these three variables impact entrepreneuship intentions directly, while all other factors exercise their influence on intentions through these three immediate antecedents (i.e., indirectly). Consistent with Ajzen's (1991) theorization, this study submits that EE's interaction with EI is mediated by students' attitudes, subjective norms and perceived behavioral controls.

Having discussed the constitutive elements of the Theory of Planned Behavior and its associated variables, these variables are unravelled to discern their individual nature. Firstly, attitude relates to an individual's predisposition towards a subject or phenomenon (Tshikovhi \& Shambare, 2015). Attitudes can be desirable or undesirable depending on the situated conditions under which such attitudes are generated. Since $\mathrm{EE}$ is a presage factor that shapes attitudinal dispositions, it can influence positively or negatively students' inclination towards entrepreneurship behavior, as reported in previous studies. Packham et al. (2010) postulate that attitudes towards entrepreneurship are an integral part of measuring EI, which are considered to be an excellent predictor of planned behavior to start new business ventures.

Subjective norms relate to the effect of an individual's significant others (e.g., educators, mentors, knowledgeable colleagues, parents and siblings) on his/her intention to engage in a particular behavior (Malebana \& Swanepoel, 2015). This is subject to the strength of one's normative beliefs (Ajzen, 2015) meaning the efficacy of significant others' influence on an individual's behavior is subject to their moral dispositions. Our inference is that if one's moral compass dictates that they recognize and value the perspectives and opinions of their significant others, their approval and endorsement of their entrepreneurial intentions will compel him/her to consider entrepreneurship seriously. The stronger the belief, the more susceptible one becomes to the influence of those close to him or her and the reverse holds true. In the context of this study, friends, family, relatives and work-mates are postulated to either enhance or undermine an individual's willingness to embark on entrepreneuship career paths.

Perceived behavioral control relates to an individual's confidence in their ability to undertake and manage a particular course of action. To the extent that it is tied to one's perception of the extent of difficulty of the course of action or task in question, it can be conceived as an expression of one's selfefficacy. As such, perceived behavioral control is often used interchangeably with Bandura's concept of self-efficacy (Kjellman \& Ehrsten, 2006). Past studies have predominantly revealed that amongst the three antecedents of EI, perceived behavioral control is the variable most susceptible to $\mathrm{EE}$ (Raposo \& Paço, 2011; Malebana, 2014; Malebana \& Swanepoel, 2015). In addition, extant literature suggests that perceived behavioral control has the greatest explanatory power on EI (Fayolle, Gailly, \& Lassas-Clerc, 2006; Ferreira, Raposo, \& Rodrigues, 2012).

Overall, there is convergence of opinion on the potential mediation of entrepreneuship educationentrepreneuship intention relationship by psychological states such as attitude, subjective norms and perceived behavioral controls (Vinogradov, Kolvereid, \& Timoshenko, 2013; Bae et al., 2014, Malebana, 2014; Kautonen, Gelderen,\& Fink, 2015).

\section{Literature review}

Since the bulk of current social psychology theories explains EI in terms of both endogenous and exogenous factors, we argue that exposure to EE can influence an individual's willingness to choose entrepreneurship as a career. Informed by this view, we postulate that the EE-EI relationship is not direct and automatic one, as there are multiple individual and psychological states that mediate this relationship. Consistent with this premise and the Theory of Planned Behavior, the literature review discusses entrepreneurial education as predictor variable, psychological dispositions such as attitudes, subjective norms and perceived behavioral control as mediating variables and entrepreneuship intentions as the response variable. The three sets of variables are elaborated in the subsequent sections of this study.

3.1. Entrepreneurship education. The definition of entrepreneurship education is contested and influx. Fayolle, Gailly,\& Lassas-Clerc (2006, p. 702) define it as "....any pedagogical program or process of edu- 
cation for entrepreneurial attitudes and skills, which involves developing certain personal qualities". Therefore, EE encapsulates the inculcation of new ventures creation of mind-sets, values and attitudes. The assumption is that imparting these skills will not only lead to their acculturation in individuals, but rather their ultimate manifestation and transfer to other contexts (i.e., non-academic, professional contexts). Thus, assumption is very problematic, as it has little resonance with the Zimbabwean tertiary education-based entrepreneurship, where such program have not wielded profound entrepreneurship culture, judging from paucity of innovation - based ventures.

The art of entrepreneurship is sophisticated and technical, one that requires entrepreneurs to possess mindsets and skills inventories relevant to the specific context of new venture creation if they were to make any meaningful contribution to the economy (Rambe et al., 2015). Since EE is founded in the transferability of entrepreneurial skills, it is envisaged that $\mathrm{EE}$ has the potential to equip students with the requisite knowledge, attributes and capabilities for new venture creation and management (Mwiya, 2014).

Extant literature shows that EE has a positive impact on the quality and quantity of new and existing entrepreneurs (Weber, 2012) even though this position is incongruent with the Zimbabwean scenario, where entrepreneurial "graduate vendors" are prevalent. In addition, Fayolle et al. (2006) observe that university students who are exposed to EE have a higher tendency to engage in entrepreneurship compared to those with no such exposure. Again, this position is also heavily contested in the Zimbabwean scenario, where innovation-based entrepreneurship has not flourished despite the prominence of university and college-based entrepreneurial programs and throughput of entrepreneurially trained graduates. Despite these inconclusive results, Mwasalwiba (2012) insists that EE has a potential effect on graduates' business start-ups; the academic standards of students; and alters students' entrepreneurial attitudes and intentions. However, Fayolle, Liñán, \& Moriano (2014) lament the critical methodological shortcomings in the majority of prevailing EE impact assessment studies. In view of such mixed results, there is a room to explore relationships between $\mathrm{EE}$ and $\mathrm{EI}$ including their potential mediation by intervening variables such as student attitudes, subjective norms and perceived behavioral controls.

3.2. Demographic factors. Findings from some studies provide some evidence of the direct influence of psychological traits (Ferreira et al., 2012; Gerba, 2012) and demographic variables (Davidsson 1995; Siu \& Lo, 2013) on the EI. This fact, together with the observation that the EE-EI relationship is dependent on contextual factors (Bae et al., 2014), warrants the inclusion of demographic and psychological factors and control variables in the study.
3.3. Entrepreneurship intention. The term EI refers to "the target behavior of starting a business" (Krueger, 1993, p. 6). This definition emanates from the view that the decision by an individual to engage in the new venture creation process is largely conscious and deliberate than serendipitous (Ajzen, 2015). Thus, individuals volunteer to engage in entrepreneurship. To the extent that the process of entrepreneurship, especially new venture creation, is a carefully thought out and deliberate process, Ajzen's Theory of Planned Behavior has been widely applied to explain and predict engagement and reluctance to embark on entrepreneuship behavior. This line of thinking is in consonance with Fayolle et al.'s (2014) view that intention represents one motivational aspect towards executing certain behavior including entrepreneurial behavior.

In the Zimbabwean context, there are few studies on $\mathrm{EE}$ at institutions of higher learning in the country (Hosho et al., 2013; Dabale \& Masase, 2014). Dabale and Masase (2014) examined the EI of undergraduate alumni from the Faculty of Management and Administration (FMA) who had taken an elective course in Entrepreneurship and Small Business Management in their final year of study at Africa University (Zimbabwe). The results revealed these alumni's positive attitudes and intention to engage in entrepreneurship careers. Apart from the preceding, Hosho et al. (2013) studied the EI of final year students from the School of Business at the Chinhoyi University of Technology (Zimbabwe). They observed that students who had undergone EE developed negative attitudes and behavioral intentions towards engaging in entrepreneurship. A comparison of the aforementioned studies' findings reveals sharp contrasts in terms of the impact of EE on EI at college level education regardless of the fact that the respondents were exposed to the EE programs of a similar type and for the same duration. The results affirm the prevailing inconclusiveness of EE impact studies, hence, this study.

\section{Research methodology}

The research followed a quantitative, cross-sectional and descriptive research design. This design facilitates the collection of data from a single point in time, as opposed to two or more times (Punch, 2013). The data collected related to factors such as respondents' attitudes, beliefs, emotions and perceptions towards entrepreneurship behavior.

4.1. Target population. Respondents of the study comprised 154 National certificate students from a polytechnic college in Zimbabwe. These were drawn from the following disciplines: Engineering, Applied Sciences and Commerce. The respondents were randomly selected from a target population of 600 students. Student class lists were used to compile a sampling frame from which numbers were drawn using a 
random number generator. The respondents were approached by one of the co-authors in September 2015 during lectures at this Zimbabwean polytechnic. Participation in the survey was voluntary, and there were no incentives rendered to participants. Consistent with research ethics, the respondents were notified of their right of unconditional participation or nonparticipation. The data collection instrument was a questionnaire, which comprised close-ended questions. Section A related to demographic questions. Section B comprised 5-point Likert scale, which was used to measure the numerous variables of interest (e.g., attitude, subjective norms, entrepreneurship intentions, etc) in the study.

4.2. Reliability and validity. Cronbach's alpha coefficients were used to ascertain the internal consistency of responses to questions relating to the variables in question. Put differently, reliability tests sought to determine if a group of questions measured the same construct. The following coefficients were obtained for each construct; EI (6-items) $=0.91$; attitude towards entrepreneurship $(10$-items $)=0.78 ;$ subjective norms $(11$-items $)=0.86$; perceived behavioral controls $(16$-items $)=0.93 ; \mathrm{EE}(13$-items $)=0.84 ;$ psychological variables $(18$-items $)=0.85$. Based on George and Mallery's (2016) scale, all these derived alpha coefficients ranged from good to excellent.

Validity, which ascertains whether the questionnaire items used for data collection process measures what it is meant to measure (Zikmund, Babin, Carr,\& Griffin, 2012), was ensured by using prevalidated items. The items were borrowed from Linan and Chen (2009), Mwiya (2014) and Karimi, Biemars, Maudei, Lans, Chizari, and Mulder (2015).

\section{Results}

Table 1 presents the results from analysis of demographic data of the respondents.

Table 1. Demographic profile of respondents

\begin{tabular}{|l|l|c|c|}
\hline \multirow{2}{*}{ Variable } & \multicolumn{1}{|c|}{ Category } & \multicolumn{2}{c|}{ Zimbabwe } \\
\cline { 3 - 4 } & & Frequency & $\%$ \\
\hline \multirow{4}{*}{ Gender } & Male & 102 & $66.20 \%$ \\
\cline { 2 - 4 } & Female & 52 & $33.80 \%$ \\
\hline \multirow{5}{*}{ Mare } & Below 21 & 31 & $20.10 \%$ \\
\cline { 2 - 4 } & Between 21-30 & 108 & $70.10 \%$ \\
\cline { 2 - 4 } & Between 31-40 & 14 & $9.10 \%$ \\
\cline { 2 - 4 } & $41-50$ & 1 & $0.60 \%$ \\
\cline { 2 - 4 } & 50 and above & 0 & $0 \%$ \\
\hline \multirow{4}{*}{$\begin{array}{l}\text { Highest quali- status } \\
\text { fication level }\end{array}$} & Never married & 124 & $80.50 \%$ \\
\cline { 2 - 4 } & Married & 29 & $18.80 \%$ \\
\cline { 2 - 4 } & Divorced/Separated/Widowed & 1 & $0.60 \%$ \\
\cline { 2 - 4 } & Widowed & 0 & $0 \%$ \\
\cline { 2 - 4 } & High school/Matric & 88 & $57.10 \%$ \\
\cline { 2 - 4 } & Tertiary certificate & 61 & $39.60 \%$ \\
\cline { 2 - 4 } & Other & 4 & $2.60 \%$ \\
\hline \multirow{2}{*}{} & & & $0.60 \%$ \\
\hline
\end{tabular}

\begin{tabular}{|l|l|c|c|}
\hline \multirow{4}{*}{$\begin{array}{l}\text { Current field } \\
\text { of study }\end{array}$} & Applied sciences & 30 & $19.48 \%$ \\
\cline { 2 - 4 } & Business & 31 & $20.12 \%$ \\
\cline { 2 - 4 } & Engineering & 92 & $59.75 \%$ \\
\cline { 2 - 4 } & Humanities \& Other & 1 & $0.65 \%$ \\
\hline
\end{tabular}

As shown in Table 1, the analyses of demographic factors focused on age, gender, field of study and highest level of qualification, since literature insinuates that the preceding variable can affect the levels of EI. The gender distribution of the total respondents shows that there were more males than females, with $66.2 \%$ females and $33.8 \%$ males. In terms of age group, the majority of respondents were concentrated around the 21 to 30 years age category. This was followed by the below 21, 31-40 and 41-50 years age categories, respectively. In terms of marital status, the majority of respondents were not married, followed by those who were married.

It is apparent from Table 1 that holders of high school/matric certificates were the majority, followed by tertiary certificate and diploma/degree holders, respectively. In addition, the majority of the respondents $(79.23 \%)$ were from Engineering and Applied Sciences fields of study. The remainder were from business-related and other areas of study. Given the possible influence of demographic factors on the relationships amongst the various constructs, we statistically controlled for the potential effect of such factors when we tested for the direct predictive influence of EE on EI.

The first set of analyses examined the existence of any relationships amongst attitude towards entrepreneurship, subjective norms and perceived behavioral control, on the one hand, and EI of respondents, on the other hand. This was done using Spearman's correlation coefficient. The choice of this non-parametric technique was informed by the lack of normality of the datasets, as determined using the Kolmogorov-Smirnov (KS) test.

As can be seen in Table 2, all three antecedents of EI had positive and statistically significant correlations with EE, albeit with varying degrees of strength. Based on Cohen's (1988) scale, subjective norms and perceived behavioral control had a positive and moderate relationship with EE. In addition, a weak correlation was revealed between attitude and EE.

Table 2. Correlations (EE versus the antecedents of EI)

\begin{tabular}{|l|c|c|}
\hline \multicolumn{1}{|c|}{ Variables } & Correlation coefficient & $p$-value \\
\hline Attitude & 0.255 & 0.000 \\
\hline Subjective norms & 0.402 & 0.000 \\
\hline Perceived behavioral control & 0.487 & 0.000 \\
\hline
\end{tabular}

Table 3 presents the results obtained from the multiple regression analyses testing the predictive effect of attitude towards entrepreneurship, subjective norms and perceived behavioral controls on the EI of respondents. 
Table 3. Attitude, subjective norms and perceived behavioral controls predicting EI

\begin{tabular}{|l|c|c|c|c|c|}
\hline \multicolumn{1}{|c|}{ Variable } & $B$ & $S E$ & $\beta$ & $t$ & $P$ \\
\hline (Intercept) & 2.80 & 2.94 & 0.00 & 0.95 & 0.342 \\
\hline $\begin{array}{l}\text { Total attitude towards } \\
\text { entrepreneurship }\end{array}$ & 0.47 & 0.07 & 0.52 & 7.20 & $<0.001$ \\
\hline Total subjective norms & -0.06 & 0.05 & -0.08 & -1.14 & 0.255 \\
\hline $\begin{array}{l}\text { Total perceived behav- } \\
\text { ioral control }\end{array}$ & 0.11 & 0.04 & 0.20 & 2.63 & 0.009 \\
\hline
\end{tabular}

Note: $F(3,150)=31.67, p<0.001, R^{2}=0.39$

From these data, the proposed regression model had a significant predictive effect on EI $\left[F(3,150)=31.67, p<0.001, R^{2}=0.39\right]$. This means that $39 \%$ of the variance in EI score is collectively explained by attitude towards entrepreneurship, subjective norms and perceived behavioral control. Further analysis of the results reveals that only attitude towards entrepreneurship and perceived behavioral control had statistically significant effect, as shown by their respective $p$-values of less than 0.01. A unit change in the value of attitude towards entrepreneurship causes a 0.47 unit change in the value for EI. In addition, a 1 unit change in perceived behavioral control explained 0.11 unit change in EI.

Table 4. Correlation of EI and control variables

\begin{tabular}{|l|c|c|}
\hline \multirow{2}{*}{\multicolumn{1}{|c|}{ Variables }} & \multicolumn{2}{c|}{ Entrepreneurial intention } \\
\cline { 2 - 3 } & Correlation & $p$-value \\
\hline Gender & 0.026 & 0.752 \\
\hline Age & 0.011 & 0.888 \\
\hline Marital status & 0.094 & 0.245 \\
\hline Highest qualification level & 0.072 & 0.373 \\
\hline Current field of study & 0.073 & 0.367 \\
\hline
\end{tabular}

Table 5. Summary of hierarchical multiple regression analysis test results

\begin{tabular}{|c|c|c|c|c|c|c|c|c|}
\hline & & $\mathrm{B}$ & $S E$ & $B$ & $t$ & $p$ & tolerance & VIF \\
\hline \multirow{2}{*}{ Model 1} & Intercept & 15.008 & 3.307 & & 4.538 & 0.000 & & \\
\hline & Psychological factors & 0.138 & 0.044 & 0.248 & 3.127 & 0.002 & 1 & 1 \\
\hline \multirow{3}{*}{ Model 2} & Intercept & 12.958 & 3.597 & & 3.61 & 00.00 & & \\
\hline & Psychological factors & 0.098 & 0.057 & 0.176 & 1.724 & 0.087 & 0.605 & 1.654 \\
\hline & $\mathrm{EE}$ & 0.225 & 0.141 & 0.148 & 1.598 & 0.112 & 0.733 & 1.364 \\
\hline \multicolumn{9}{|c|}{ *Dependent variable: El } \\
\hline \multicolumn{9}{|c|}{${ }^{* *}$ Predictor variables: Model 1 Psychological factors; Model 2 Psychological factors and entrepreneurship } \\
\hline Education & & & & & & & & \\
\hline
\end{tabular}

Notes: Model 1: $\mathrm{R}^{2}=0.0062, \mathrm{p}=0.002$, Model 2: $\mathrm{R}^{2}=0.00792, \mathrm{p}=0.259$.

\section{Discussion}

The rationale of this study was to ascertain the impact of EE on the EI of vocational education students in the developing world context. The first question in this research was whether a statistically significant relationship existed between EE and attitude towards entrepreneurship. The results of this study affirmed statistically significant relationships between $\mathrm{EE}$ and each of the precursors of entrepreneurial intention (i.e., attitude towards

\begin{tabular}{|l|l|l|}
\hline $\begin{array}{l}\text { Psychological factors (need for } \\
\text { achievement, } \\
\text { locus of control and risk-taking propen- } \\
\text { sity) }\end{array}$ & 0.344 & 0.000 \\
\hline
\end{tabular}

The study also examined whether entrepreneurship has a direct effect on EI. A hierarchical regression model was used to assess whether EE directly predicted EI. In this model, EE was the independent variable, while EI was the dependent variable. Given that some psychological factors such as need for achievement, locus of control and risk-taking propensity had revealed a positive correlation with EI (see Table 4), they were also included in the test as control factors. Psychological factors were the only independent variable at Stage 1 of the equation, which is Model 1 of the regression model, to control for psychological factor-influenced responding. EE was, then, included as an additional independent variable in Stage 2, which is Model 2.

The results for Model 1 demonstrate that psychological factors, on their own, had a statistically significant $(p=0.002)$, but weak predictive effect on EI (Adjusted R Square $=0.056$ ). This means that they directly explained approximately $6 \%$ of the variance in EI. Surprisingly, the introduction of EE as an additional independent variable did not add any significant predictive power to the model, as shown by the non-significant effect $p$-value of 0.259 . An examination of the $p$-values of the standardized coefficients for the individual predictor variables shows that all the predictors had no statistically significant $p$-values (psychological factors $=0.087, \mathrm{EE}=0.112$ ). From the results of the regression analysis, it can be concluded that EE did not have a statistically significant and direct predictive influence on EI. entrepreneurship and perceived behavioral control). Using Cohen's (1988) standards of categorizing the strength of correlations, the correlation coefficient is positive, but weak $(r=0.255)$. The study affirms Manuere, Danha and Majoni's (2013) observation that students' attitude towards entrepreneurship is positively correlated to their previous exposure to EE. This implies that an improvement in EE is associated with a more favorable attitude towards entrepreneurship careers. 
The second research question was whether a statistically significant relationship existed between EE and subjective norms. The results of the correlation analysis suggest a positive and significant correlation between $\mathrm{EE}$ and subjective norms of respondents $(r=0.402, p<0.000)$. The findings of the current study are consistent with those of Karimi, Biemans, Lans, Chizari, and Mulder (2014) and Souitaris et al., Zerbinati and Al-Laham (2007) whose studies revealed a positive correlation between EE and subjective norms. The interpretation is that the exposure of students to EE is linked to enhanced levels of subjective norms.

Another question was if there is a statistically significant relationship between EE and perceived behavioral control. The results confirmed a moderate and positive correlation between the two variables $(\mathrm{r}=0.487, \mathrm{p}<0.000)$. Hence, an increase in the EE score is associated with a higher perceived behavioral control score. The finding seems to be consistent with other studies, which revealed similar results (Linan, 2008; Mueller, 2011; Hattab, 2014; Oyugi, 2014).

Having noted the significant positive correlations between EE and the antecedents of EI, the study also ascertained if these precursors predicted the actual EI of respondents. Even though the results reveal that the three antecedents explained $39 \%$ of the variance in EI, only attitude towards entrepreneurship and perceived behavioral control had a significant predictive effect. Even though there are some studies that confirm the significant predictive effect of all three factors (provided these studies here), our findings corroborate those of other scholars who have found the predictive effect of subjective norms to be not significant (Linan \& Chen, 2009; Malebana, 2012; Lortie \& Castogiovanni, 2015). Precisely, it is due to this persistent lack of significant results that some scholars have pointed out that subjective norms indirectly influence EI through other antecedents, such as attitude and perceived behavioral control (Liñán et al., 2011; Ferreira, Raposo, Rodrigues, Dinis, \& Paço, 2012).

Lastly, the study also sought to establish if EE has a direct effect on EI, whilst controlling for other intervening factors. Contrary to expectations, the results of the hierarchical regression analysis demonstrated that EE did not have a direct, significant, predictive effect on EI. This is in spite of EE having a significant positive and moderate correlation with EI. A possible explanation for this anomaly is the interference of demographic and other psychological factors in the relationship. However, the outcome underscores the relevance of Liñán et al. (2011), Knabe (2012) and Ajzen's (2015) caveat that even though intention levels may have positive associative linkages with several endogenous and exogenous factors (e.g., demographic and personal- ity), such factors do not exercise a direct predictive influence on the intentions. Instead, their impact is mediated by attitude, subjective norms and perceived behavioral control.

\section{Recommendations}

Given the significant, but indirect relationship between EE and EI, we recommend the adoption of EE across institutions of higher learning. Since the relationship is not direct (meaning there are other endogenous or exogenous variables that affect the linkage), entrepreneurship educators need to establish a wide range of criteria in their selection of those to enrol of EE so as to target those with particular psychological dispositions towards creation and ownership of new ventures.

In line with the preceding, there may be a need to introduce screening interviews as admission mechanism into EE programs, while avoiding the danger of being accused of being discriminatory. For instance, business-related or practically-oriented psychometric tests may be used to increase chances of recruiting students with the appropriate entrepreneurially-oriented dispositions. According to Weber (2012), it is wasteful to invest resources in maximizing the number of individuals undergoing $\mathrm{EE}$ and taking this as an impact measure. The reason for such scepticism is because some individuals may not wish to engage in entrepreneuship careers at all even after participating in an EE program. Thus, it will be more sensible to prioritize the participation of those already favorably inclined towards entrepreneurship.

In addition, entrepreneurship educators need to develop program curricula that encompass entrepreneuship skill inventories, which capture both psychological traits (e.g., risk-taking propensity, opportunity recognition) and the mediating factors (attitude, subjective norms and perceived behavioral control) discussed in this study to ensure more resonance of training programs with productive entrepreneuship outcomes.

\section{Implications for future research}

The current study was a one institution survey, limits its extent of generalization across various tertiary learning institutions (i.e., universities and colleges) in Zimbabwe. Future studies need to rollout larger surveys covering several Zimbabwean polytechnic colleges and universities to determine if similar results will be obtained.

The study also adopted a cross-sectional design, which allowed the researchers to develop a panoramic snapshot of the EE-EI relations among college students over a particular point in time, but denied them the opportunity to explore the relationships between variables over extended time. This was due to financial and time constraints. Future 
studies may be needed to adopt a trace studies approach to determine if those students who claimed to possess entrepreneuship intentions would have pursued such intentions by creating their own ventures. It may not be clear whether the harsh economic climate and the weak innovative culture in the country could have shaped the results. As such, cross-national comparative studies covering Zimbabwean and its neighboring countries may need to be conducted to determine other country-specific peculiarities (e.g., entrepreneurial culture, innovation cultures, and ethnic background) that may shape entrepreneuship intentions other than those covered in this investigation.

\section{Conclusion}

This paper discussed the fundamental importance of EE in encouraging the pursuit of entrepreneuship careers by vocational education students in a struggling economy context. Even though the study outcomes revealed that EE did not have a direct influence on EI of the respondents, it had an indirect impact through three factors namely attitudes towards entrepreneurship, subjective norms and perceived behavioral control. The results also proved the collective predictive effect of attitude towards entrepreneurship, subjective norms and perceived behavioral control on entrepreneurship, thus, validating Ajzen's Theory of Planned Behavior as a framework for explaining entrepreneurship behavior.
Overall, these findings provide some support for the conceptual premise that it is possible to enhance vocational students' inclination towards entrepreneurship careers by exposing them to interventions like EE. This is because of the positive effect the entrepreneurial education had on students' attitudes and perceived behavioral control. Whilst this study did not confirm the direct cause and effect relationship between EE and EI, the linkages it identified assist in understanding the role of the vocational education sector in the development of potential entrepreneurs in a poverty stricken, economically depressed economy. Hence, this information can be used to develop targeted interventions aimed at promoting nascent entrepreneurship.

However, these findings are limited by the use of a cross-sectional design. Richer revelations can emerge from the employment of longitudinal studies in which students' EI are evaluated at particular time intervals (e.g., after a very 3-5 years) after their exposure to EE. Also, the sample was not nationally representative of Zimbabwean vocational education students, since respondents were selected from a single institution. Further research may explore the same research area using respondents from different vocational education institutions,- as well as adopt a longitudinal.

\section{References}

1. Ajzen, I. (2015). Consumer attitudes and behavior: the theory of planned behavior applied to food consumption decisions. Rivista di Economia Agraria, 70(2), 121-138.

2. Bae, T. J., Qian, S., Miao, C., and Fiet, J. O. (2014). The Relationship Between EE and Entrepreneurial Intentions: A Meta-Analytic Review. Entrepreneurship: Theory and Practice, 38(2), 217-254.

3. Bhebe, Q., and Mahapa, M. (2014).The Decline in Trade Union Density in the 21stcentury in Zimbabwe. A case of Zimbabwe Congress of Trade Union (ZCTU). Journal of Human Resources, 2(1), 67-82.

4. Brixiova, Z., Ncube, M., and Bicaba, Z. (2015). Skills and Youth Entrepreneurship in Africa: Analysis with Evidence from Swaziland,67, 11-26.

5. Cohen, J. (1988). Statistical power analysis for the behavioral sciences (2nd ed.). Hillsdale, NJ: Erlbaum.

6. Davidsson, P. (1995). Determinants of entrepreneurial intentions. Paper presented at the RENT IX Conference, Workshop in Entrepreneurship Research, Piacenza, Italy, November 23-24.

7. Fayolle, A., and Gailly, B. (2008). From craft to science: Teaching models and learning processes in EE. Journal of European Industrial Training, 32(7), 569-593.

8. Fayolle, A., Gailly, B., and Lassas-Clerc, N. (2006). Effect and Counter-effect of EE and Social Context on Student' s Intentions. Estudios de Economia Aplicada, 24, 509-523.

9. Fayolle, A., Liñán, F., and Moriano, J. A. (2014). Beyond entrepreneurial intentions: values and motivations in entrepreneurship. International Entrepreneurship and Management Journal,10(4), 679-689.

10. Ferreira, J., Raposo, L., and Rodrigues, R. G. (2012). A model of entrepreneurial intention An application of the psychological and behavioral approaches. Journal of Small Business and Enterprise Development, 19(3), 420-440.

11. George, D., and Mallery, P. (2016). IBM SPSS Statistics 23 Step by Step: A Simple Guide and Reference. London: Routledge.

12. Gerba, D. T. (2012). Impact of EE on entrepreneurial intentions of business and engineering students in Ethiopia. African Journal of Economic and Management Studies, 3(2), 258-277.

13. Hattab, H. W. (2014). Impact of EE on Entrepreneurial Intentions of University Students in Egypt. Journal of Entrepreneurship, 23(1), 1-18.

14. Karimi, S., Biemans, H. J. A., Lans, T., Chizari, M., and Mulder, M. (2014). The Impact of EE: A Study of Iranian Students' Entrepreneurial Intentions and Opportunity Identification. Journal of Small Business Management,54(1), 187-209.

15. Karimi, S., Biemans, H. J. A., Mahdei, K. N., Lans, T., Chizari, M., and Mulder, M. (2015). Testing the relationship between personality intentions in a developing country. International Journal of Psychology, 1-15. 
16. Kautonen, T., Gelderen, M., and Fink, M. (2015). Robustness of the theory of planned behavior in predicting entrepreneurial intentions and actions. Entrepreneurship Theory and Practice, 39(3), 655-674.

17. Kirzner, I. M. (1999). Creativity and/or alertness: A reconsideration of the Schumpeterian entrepreneur. The Review of Austrian Economics, 11(1), 5-17.

18. Kjellman, A., and Ehrsten, M. (2006). A Theory of Homo Entreprenaurus. Research on Technological Innovation, Management and Policy,9(05), 211-232.

19. Knabe, A. (2012). Applying Ajzen 's Theory of Planned Behavior to a Study of Online Course Adoption in Public Relations Education. Unpublished PhD thesis: Marquette University.

20. Linan, F. (2008). Skill and value perceptions: how do they affect entrepreneurial intentions?. International Entrepreneurship and Management Journal,4(3), 257-272.

21. Liñán, F., and Chen, Y. (2009). Development and cross-cultural application of a specific instrument to measure entrepreneurial intentions. Entrepreneurship Theory and Practice, 593-617.

22. Liñán, F., Rodríguez-Cohard, J. C., and Rueda-Cantuche, J. M. (2011). Factors affecting entrepreneurial intention levels: A role for education. International Entrepreneurship and Management Journal, 7(2), 195-218.

23. Lortie, J., and Castogiovanni, G. (2015). The theory of planned behavior in entrepreneurship research: what we know and future directions.International Entrepreneurship Management Journal, 11, 935-957.

24. Malebana, M. (2014). The relationship between exposure to EE and entrepreneurial self-efficacy.South Africa Business Review, 18(1), 1-26.

25. Malebana, J. (2014). Entrepreneurial intentions of South African rural university students: A test of the theory of planned behavior. Journal of Economics and Behavioral Studies, 6(2), 130-139.

26. Malebana, M. J., and Swanepoel, E. (2015). Graduate entrepreneurial intentions in the rural provinces of South Africa.South Africa Business Review, 19(1), 89-111.

27. Maritz, A., and Brown, C. R. (2013). Illuminating the black box of EE programs. Education and Training, 55(3), 234-252.

28. Mueller, S. (2011). Increasing Entrepreneurial Intention: Effective Entrepreneurship Course Characteristics. International Journal of Entrepreneurship and Small Business, 13(1), 55-74.

29. Murinda, E. (2014). Skill training and employment situation of young people in Zimbabwe : An analysis of the technical and vocational education and training (TVET) and employment situation among young people in Zimbabwe, 2014 Ministerial Conference on Youth employment, Abidjan, Ivory Coast, July.

30. Mushipe, Z. J. (2013). Entrepreneurship Education - An Alternative Route to Alleviating Unemployment and the Influence of Gender : An Analysis of University Level Students ' Entrepreneurial Business Ideas, International Journal of Business Administration, 4(2), 1-7.

31. Mwasalwiba, E. (2012). EE: a review of its objectives, teaching methods, and impact indicators. Education+Training,40(2), 72-94.

32. Oosterbeek, H., van Praag, M., and Ijsselstein, A. (2010). The impact of EE on entrepreneurship skills and motivation. European economic review, 54(3), 442-454.

33. Oyugi, J. L. (2014). Effectiveness of the methods of teaching entrepreneurship courses to developing self-efficacy and intention among university students in Uganda. International Journal of Social Sciences and Entrepreneurship, 1(11), 491-513.

34. Packham, G., Jones, P., Miller, C., Pickernell, D., and Thomas, B. (2010). Attitudes towards EE: a comparative analysis. Education + Training,52(8/9), 568-586.

35. Pouratashi, M. (2015). Entrepreneurial Intentions of Agricultural Students : Levels and Determinants. The Journal of Agricultural Education and Extension, 21(5), 467-477.

36. Pruett, M. (2012). EE: Workshops and Entrepreneurial Intentions.Journal of Education for Business, 87(2), 94-101.

37. Punch, K. F. (2013). Introduction to social research: Quantitative and qualitative approaches. London: Sage.

38. Raposo, M., and Paço, A. (2011). EE: Relationship between education, Psicothema, 23(2001), 453-457.

39. Roxas, B. (2014). Effects of entrepreneurial knowledge on entrepreneurial intentions: a longitudinal study of selected South-east Asian business students.Journal of Education and Work, 27(4), 432-453.

40. Rusvingo, S. L. (2015). The Zimbabwe Soaring Unemployment Rate of 85\%: A Ticking Time Bomb Not Only for Zimbabwe but the Entire SADC Region. Journal of Management and Business Research, 14(9), 1-14.

41. Siu, W. S., and Lo, E. S. C. (2013). Cultural contingency in the cognitive model of entrepreneurial intention. Entrepreneurship Theory and Practice, 37(2), 147-173.

42. Souitaris, V., Zerbinati, S., and Al-Laham, A. (2007). Do entrepreneurship programmes raise entrepreneurial intention of science and engineering students? The effect of learning, inspiration and resources. Journal of Business Venturing,22(4), 566-591.

43. Tshikovhi, N., and Shambare, R. (2015). Entrepreneurial knowledge, personal attitudes, and EI among South African Enactus students intentions among South African Enactus students. Problems and Perspectives in Management, 13(1), 152-158.

44. Vinogradov, E., Kolvereid, L., and Timoshenko, K. (2013). Predicting entrepreneurial intentions when satisfactory employment opportunities are scarce. Education+ Training, 55(7), 719-737.

45. Weber, R. (2012). Evaluating EE. Munich: Springer Fachmedien Wiesbaden.

46. Weber, R., Graevenitz, G. von, and Harhoff, D. (2009). The Effects of EE Richard Weber and Georg von Graevenitz and Dietmar Harhoff Munich School of Management University of Munich at f “ ur Betriebswirtschaft at $\mathrm{M} *$ unchen Online at http://epub.ub.uni-muenchen.de/ The Effects of Entre.

47. Zikmund, W., Babin, B., Carr, J., and Griffin, M. (2012). Business research methods. Cengage Learning. 